\title{
Карабахский вопрос в период руководства Азербайджаном Гейдара Алиева (1970-80-е годы)
}

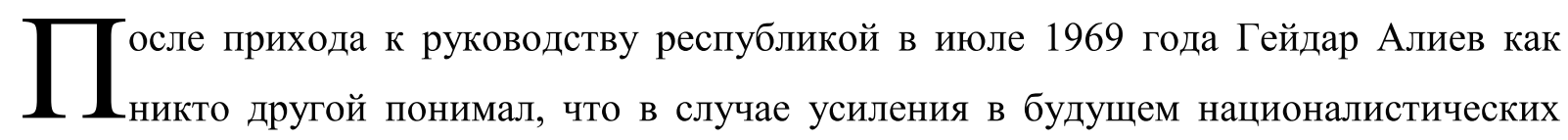
настроений в НКАО не меньшая ответственность будет лежать на партийном руководстве области. Поэтому Алиев, прежде всего, решает укрепить руководство автономной области проверенными кадрами. Осенью 1973 года он предложил избрать первым секретарем Нагорно-Карабахского обкома Компартии Азербайджана Бориса Кеворкова до этого работавшего первым секретарем Кировского райкома партии Баку.12 октября 1973 года состоялся пленум Нагорно-Карабахского обкома КП Азербайджана, в соответствие с решением которого Гурген Мелкумян был освобожден от обязанностей первого секретаря и члена бюро Нагорно-Карабахского обкома, а на его место был избран Борис Кеворков. Мелкумяна перевели на работу в $\mathrm{ACПC}^{77}$. Кеворков был первым руководителем армянской автономии, не имевшим карабахское происхождение (он был из Шемахи), занимал пост первого секретаря обкома НКАО дольше всех своих предшественников -15 лет и был освобожден от должности лишь после начала конфликта в феврале 1988 года. Позже, в интервью российскому журналисту А.Караулову Г.Алиев в целом положительно оценил его деятельность на этом посту: «Все руководители Нагорно-Карабахской автономной области- армяне. Считаю, что они вели правильную политику и правильно осуществляли руководство; и я, например, каких-либо серьезных нарушений со стороны руководства НКАО не замечал» $^{78}$. Алиев провел также ряд других кадровых перестановок в руководстве Нагорного Карабаха: «Первым заместителем председателя областного совета

\footnotetext{
77 Мирзоян Г. «Эскизы к биографии. От Геворга Алиханяна до Сурена Арутюняна» Газетная версия книги. https://forum.hayastan.com/topic/39542-г-мирзоян-«советские-правители-армении»/

${ }^{78}$ Караулов А. Вокруг Кремля. Книга политических диалогов. В 2-х частях, часть 1. М., 1990, с.251-252.
} 
я назначил азербайджанца. Я направлял туда работать азербайджанцев» ${ }^{79}$. Этот факт подтверждают и местные армянские партийные кадры. Мушег Оганджанян, полгода проработавший с Кеворковым в должности председателя облсовета народных депутатов НКАО (1962-1974), вспоминал: «В 1973-1974 гг. все руководство области заменили «посланцами» из Баку - Кеворков, Асланов, Мурадов, Самвелов и другие «ОВ》-Ы ${ }^{80}$.

Ильгусейн Гусейнов, который долгие годы проработал на высоких должностях в органах госбезопасности республики, вспоминал : «70-е годы были характерны уже тем, что армянские националисты открыто поднимали вопрос «об исторической принадлежности территории Карабаха Армении». Основная роль в этой «деятельности» принадлежала части интеллигенции и молодежи области, действия которых направлялись националистическими кругами Еревана. В 1972-1974 годы только на территории области по материалам КГБ Азербайджана были профилактированы 35 лиц армянской национальности, части которой было объявлено официальное предупреждение» ${ }^{81}$.

Всегда держа руку на пульсе, армянские националисты традиционно поднимали вопрос о пересмотре границ с Азербайджаном в период важных политических перемен или накануне знаменательных событий в истории страны или республики. Так произошло в 1972 году, когда вся страна готовилась к празднованию 50-летия образования СССР и в 1973 году, когда страна только оправилась от торжеств, посвященных 50-летию образования СССР, а в Азербайджанской ССР шла подготовка к празднованию 50-й годовщины образования Нагорно-Карабахской автономной области.

В своих воспоминаниях один из руководителей Международного отдела ЦК КПСС К Брутенц (армянин-И.Н.) писал : «В 1972 году руководство Армении улучив момент, когда М.Суслов был в отпуске и секретариат вел А.Кириленко, официально выступило с инициативой о воссоединении Карабаха с Арменией. Постановлением секретариата руководителям Армении и Азербайджана было поручено совместно изучить поставленный вопрос и предложить его решение. Руководящие «четверки» (1-й и 2 -й секретари ЦК, председатели Совминов и Президиумов Верховных Советов) с обеих сторон провели в один из уик-эндов двухдневную встречу (по одному дню

\footnotetext{
${ }^{79}$ Алиев Г. Наша независимость вечна. Многотомник. Том 23. Баку, 2008, с.95.

${ }^{80} \mathrm{http}$ ://www.aniarc.am/2015/04/30/karabakh-diary-russian-kevorkov/

${ }^{81}$ Гусейнбейли А. Интервью с генералом разведки. Баку, 1997, с.57-58
} 
н территории каждой из республик), но ни к какому соглашению не пришли. Азербайджанские представители, как и следовало ожидать, приняли предложение Еревана в штыки. В конце концов, под давлением армянской стороны условились, что встретятся вновь, но в более узком составе для выработки, учитывая постановление секретариата, хоть какой-то совместной записки. Однако запланированная встреча не состоялось : руководители Азербайджана съездили к отдыхавшему в Минеральных Водах Суслову и тот по возвращении в Москву добился от Брежнева указания Еревану «отозвать свою записку», что и было сделано» ${ }^{82}$.

В 1972 году из Еревана в Москву, Генеральному секретарю ЦК КПСС Л.Брежневу было отправлено письмо от представителей армянской интеллигенции, в которой её авторы считали нецелесообразным разъединение Армянской ССР от Нагорного Карабаха. Давая в письме краткую историческую справку вопроса, они всю вину возложили на Зиновьева, Багирова и Берия, которые якобы отменили «справедливые» решения «от 1 декабря 1920 года Бакинского Совета и июньского соглашения правительств Азербайджанской ССР и Армянской ССР от 1921 года о передачи Нагорного Карабаха Армении». Выбор этих лиц в качестве виновников был не случаен. Зиновьев, хотя и был в числе жертв сталинских репрессий, однако не был реабилитирован после ХХ съезда КПСС 1956 года. Багиров и Берия наоборот считались основными организаторами сталинских репрессий. Таким образом, армянам удобно было списать все ошибки большевиков в национальной политике на политических деятелей, имена которых числились в списке врагов народа. Но самое интересное, что фамилии ни одного из них никогда не фигурировали среди участников различных заседаний, не упоминались в партийных переписках 1920-х годов, касавшихся вопроса о территориальном конфликте между Арменией и Азербайджаном. В то же время авторы обращения были уверены, что «маленькое изменение республиканских границ», то есть передача Нагорного Карабаха Армении не помешает братской дружбе, поскольку « в течение пятидесяти лет Советской власти наши народы воспитывались в духе интернационализма». В качестве примера приводились указы Президиума Верховного Совета СССР от января и февраля 1972 года о частичном изменение границ между Узбекской ССР и Киргизской ССР, а также Узбекской ССР и Таджикской ССР.

\footnotetext{
${ }^{82}$ Брутенц К. Тридцать лет на Старой площади. Москва, 1998, с.510
} 
В конце письма выражалась просьба накануне 50-летия образования Советского Союза разрешить вопрос воссоединения Нагорного Карабаха с Советской Арменией ${ }^{83}$.

Почти одновременно на имя Л.Брежнева было отправлено обращение от т.н. представителей общественности НКАО, содержание которой было выдержано в самых лучших традициях армянства. Авторы письма наряду с требованиями о передачи Нагорного Карабаха Армении, не забыли затронуть в ней тонкую струну о вековой преданности армян большому русскому народу, о недоверии мусульманам. Утрируя реальность, выдавая желаемое за действительное, авторы обращения полностью игнорировали успехи в развитии области за прошедшие 50 лет. Опустив традиционный армянский опус о прошлом Карабаха, приведем некоторые отрывки из письма, где авторы описывали «настоящее» состояние края: « Пользуясь доверием и невмешательством Москвы, руководство республики всячески старается урезать не только территорию, но и правовые возможности Карабаха. Оставленные Карабаху скудные земли, медленно, но планомерно урезаясь присоединяются к обширным равнинам соседних районов Азербайджана. Даже реки и ручейки невправе орошать земли Карабаха. Только незначительная часть водных ресурсов области могут пропитать её землю. В то время, когда сады и посевы Карабаха гибнут от засухи, на дворах у населения соседних районов республики настоящий рай. И от их каприза зависит снабжение Карабаха овощами, фруктами, зерном, бахчевым и прочими. Мало того, в последнее времена усиливается заселение области азербайджанцами. Понятно, что после этого резко ускорился процесс вынужденной эмиграции армянского населения Карабаха по всему Союзу. А уходит потому, что ему очень трудно достать пропитание для своей семьи, ....во всей республике имеется всего один филиал высшего учебного заведения на 75 мест и два филиала техникумов,...закрыты все армянские театры и журналы, кроме одного, оставленного на хозрасчет в столице области, ...чем дальше -тем труднее сохранить свой язык и нравы» и т.д. Интересно, что авторы письма, видимо, поняв как далеко они зашли в своих фантазиях, просили не удивляться необычному тону обращения, которое они преподносили «от имени всего прогрессивного человечества». В конце письма досталось и руководителям области, вину которых видели в молчание и примирение с положением в Карабахе ${ }^{84}$.

\footnotetext{
83 Борьба армян за воссоединение НКАО с Советской Арменией. Сборник документов и материалов. Ереван. 2011, с.84-85

${ }^{84}$ Там же, с.85-90
} 
Письма подобного содержания, в которых армянские националисты для обоснования своих претензий на Нагорный Карабах делали, прежде всего, упор на якобы экономическую отсталость края и низкие капиталовложения в НагорноКарабахскую Автономную область по сравнению с другими районами Азербайджанской ССР, ущемление политических и культурных прав армянского населения, попытки азербайджанского руководства искусственно изменить демографическую ситуацию в автономии за счет вытеснения армян и расселения здесь азербайджанцев, направлялись партийному руководству в Москве и в последующем.

Конечно, это было всего лишь ширмой, прикрытием истинной цели дискредитировать в глазах центра партийное руководство республики и отторгнуть Нагорный Карабах от Азербайджана. В интервью российскому журналисту Андрею Караулову на вопрос о том, что можно ли отнести к причинами конфликта ущемление прав армянского населения Нагорного Карабаха, недостатки в социальноэкономическом развитии области, Г.Алиев дал довольно подробный ответ, аргументировав их конкретными фактами и цифрами: «К сожалению, после того как в этой области обострилась ситуация, появилось мнение о том, что причиной конфликта стало отставание Нагорного Карабаха в социально-экономической сфере и, даже, якобы неправильное отношение к проблемам НКАО, к его населению со стороны бывшего руководства республики». Алиев привел конкретные факты, свидетельствующие о высоких показателях социально-экономического развития НКАО в 70-е-80-е годы: « По показателям социально-экономического развития НКАО превосходила среднереспубликанские показатели Азербайджана и Армении. Экономика области наиболее полное развитие получила именно в 70-80-е годы. Были построены железная дорога до центра области, прекрасный вокзал в Степанакерте, новый аэропорт-мы организовали регулярные рейсы между Степанакертом, Баку и Ереваном. Я позвонил Демирчяну, и мы договорились, что рейсы будут осуществлять Аэрофлот Азербайджана и Аэрофлот Армении,- видите до каких мелочей мы обдумывали все эти вопросы. Были созданы крупные предприятия: обувная фабрика, электротехнический завод, заводы конденсаторов электронной промышленности, сельхозмашиностроения и другие. Значительные меры были предприняты и в области сельского хозяйства. Построили два крупных водохранилища с электростанцией, оросительными каналами, что значительно улучшило водоснабжение двух районов. Производство винограда выросло с 50-60 тысяч тонн в начале 70-х годов до 120-130 тысяч тонн в 1980-м. Почти в два раза увеличилось производство животноводства. 
Для небольшой области с населением в 170 тысяч человек это немало. Много было сделано и в социально-духовной сфере. В Степанакерте мы создали педагогический институт. В такой небольшой области он, может быть, и не нужен, но мы пошли навстречу пожеланиям творческой интеллигенции. Преподавание велось на армянском языке. Я уже сказал о том, что строились жилые дома, школы, поликлиники; был реконструирован и оснащен новым оборудованием драматический театр. Построили большой Дом политпросвещения, я лично был там во время строительства. Открылись новые памятники... Многим деятелям искусства были присвоены звания народных и заслуженных артистов Азербайджана. Ежегодно шел внеконкурсный прием молодежи из НКАО в высшие учебные заведения Азербайджана и страны. В городе Шуша существовала большая церковь. В 1918 году она была разрушена. Мы его полностью восстановили, пригласили мастеров из Армении. Значительно активизировались культурные связи НКАО с Арменией, и мы этому способствовали. Автономную область часто посещали руководители министерств и ведомств Армении, театры и концертные бригады, деятели культуры, ученые. Всего разговоры о какихлибо ограничениях беспочвенны» ${ }^{85}$.

Каждая поездка Г.Алиева в Нагорный Карабах, в которой он бывал иногда по нескольку раз в год, становилось знаменательным событием в жизни автономной области, поскольку сопровождалось открытием новых промышленных и социальных объектов, дорог, являлось крупным вкладом в её культурную жизнь. В октябре 1973 году Алиев находился в Степанакерте по случаю присуждения Нагорно-Карабахской автономной области переходящего Красного Знамени ЦК КПСС, СМ СССР, ВЦСПС и ЦК ВЛКСМ. Уже через месяц Гейдар Алиев участвует на торжественном заседании Нагорно-Карабахского обкома партии и областного Совета депутатов по случаю 50 -ой годовщине юбилея автономной области. В честь этой даты НКАО было удостоено орденами Ленина и Дружбы народов. Позже некоторые отечественные дилетанты обвинят Алиева в особом внимании, которое он оказывал развитию НКАО. Во время своего выступления на заседании Милли Меджлиса 23 февраля 2001 года Президент Азербайджанской республики Гейдар Алиев так ответил этим несправедливым нападкам: «Когда я руководил республикой, -это открыто следует признать, мы создавали Нагорному Карабаху более благоприятные экономические условия, отдавали предпочтение развитию его экономики. Так как постоянно вставал вопрос о том, что

\footnotetext{
${ }^{85}$ Караулов А. Вокруг Кремля. Книга политических диалогов. В 2-х частях, часть 1, с.251-252.
} 
якобы в Азербайджане зажимают Нагорный Карабах и армяне там не могут развиваться. Чтобы сохранить целостность Азербайджана, его территории мы в то время, повторяю, уделяли больше внимание Нагорному Карабаху. Я и сегодня признаю, что делал это, чтобы не дать возможность Нагорному Карабаху, армянам поднимать этот вопрос» ${ }^{86}$.

21 марта 1975 года состоялся Пленум Обкома НКАО, который позже вызвал шквал критики у армянских националистов различного калибра, посылавших многочисленные письма руководству Армении и СССР с резкой критикой в адрес партийного руководства автономной области и с требованиями её отставки. Причиной подобной реакции стало выступление на пленуме первого секретаря областного комитета партии Нагорно-Карабахской автономной области Б. Кеворкова, в которой прозвучали конкретные фамилии и факты о националистических элементах, стремившихся нарушить политическую стабильность в регионе. Так затронув в начале своего доклада текучие вопросы, Кеворков далее перешел к основной теме - борьбе «рабочего класса с буржуазным национализмом и мелкобуржуазными настроениями национального эгоизма, чванства, исключительности, замкнутости». Кеворков в резкой форме осудил попытку отдельных лиц склонить армянскую молодежь к совершению действий, наносящих ущерб «дружбе советских народов», установив, что их действия перекликаются «с идейно-политическими установками дашнакских зарубежных центров, с целями идеологических служб империализма». Первый секретарь обкома призвал коммунистов «давать принципиальный отпор любым, даже малейшим проявлениям националистических пережитков» и создать обстановку «нетерпимости к проявлениям национальной ограниченности, чуждых нравов национальной исключительности, кичливости». Далее, осуждая националистические предрассудки, Кеворков расценил как политически вредные «попытки Баграта Улубабяна (председатель союза писателей НКАО -Автор) и некоторых солидаризировавшихся с ним отсталых, идейно незрелых одиночек интерпретировать с порочных позиций национального эгоизма и национальной ограниченности вопрос о Нагорном Карабахе», а армянские притязания на Карабах в 1965-1967 годах представил как «попытки отдельных идейно незрелых лиц поднять вопрос о том, где должно быть место Нагорного Карабаха». При этом Кеворков, обращаясь к досоветскому периоду истории Карабаха, отметил, что «дашнаки усиленно добивались присоединения Нагорного

\footnotetext{
${ }^{86}$ Алиев Г. Наша независимость вечна. Многотомник. Том 32. Баку, 2010, с.164.
} 
Карабаха к дашнакской Армении, развили бурную деятельность в этом направлении...» и привел в качестве свидетельств выдержку из доклада В.Ленину А. И. Микояна от 22 мая 1919 г., а также ссылку на мнение одного из партийных руководителей Карабаха А. Каракозова, озвученном в докладе на бюро компартии Азербайджана 10 июля 1920 г. Отстаивая идею нераздельности, единства Нагорного Карабаха с Азербайджаном, Кеворков заявил участникам пленума: «Образованием Нагорно-Карабахской Автономной области в составе Азербайджанской ССР раз и навсегда был решен пресловутый «Карабахский вопрос», не раз использовавшийся империалистами и их дашнакскими и мусаватистскими агентами в антинародных целях», и в стремлении обосновать свою правоту, привел выступление одного из руководителей Азербайджанской партийной организации в 20- х годах Л. Мирзояна, который на чрезвычайном съезде второго Шушинского района 1 августа 1921 года отметил, что с экономической, духовной, политической и национальной точек зрения Карабах тесно связан с центром Азербайджана. «Второй факт, - продолжил Кеворков, - представляет собой постановление пленума Кавбюро ЦК РКП(б) от 5 июля 1921 года».

В выступлении Б. Кеворкова прозвучала жесткая критика в адрес исключительно представителей армянской интеллигенции и руководителей автономной области- поэта Богдана Джаняна, начальника управления культуры Жана Андряна, директора музея Ш.Мкртчяна, начальника статуправления Захаряна, редактора областной газеты А. Аванесяна и других, а также были приведены примеры снятия с работы, исключения из партии и т. д. Особенно Кеворков возмутился чтением студентами медучилища стихотворения «Плач Карабаха» и осудил распространение среди молодежи материалов суда над Согомоном Тейлеряном, отличившимся тем, что будучи дашнакским террористом, застрелил в 1921 году в Берлине министра внутренних дел правительства младотурок Османской Турции Талят-пашу. Осудив армян за расправу над Аршадом Мамедовым в июле 1967 г., докладчик также припомнил и взрыв гранаты в 1971 г. у Степанакертской гостиницы «Карабах». Кеворков отметил грубые ошибки, допущенные бывшим первым секретарем Г. Мелкумяном и секретарем по идеологии Н. Арутюняном ${ }^{87}$.

Выступление Б.Кеворкова, опубликованное на страницах газеты «Советский Карабах» 23 марта 1975 года, дало армянским националистам удобный повод вновь

87 Газарян В.Только разобравшись с прошлым, можно строить будущее. http://demonewspaper.com/russian/2008-2/n8-may-2008/ 
начать шумиху вокруг Нагорного Карабаха после наступившей паузы в связи проведением торжеств, посвященных 50-летию автономии. Была начата мощная компания писем и обращений в Москву. Среди авторов писем замелькали имена армянских писателей Л.Гурунца и С.Капутикян. Интересно, что в своих письмах на имя Генерального секретаря ЦК КПСС Л.Брежнева эти деятели не нашли в себе смелости открыто ставить перед московским начальством вопрос о передачи Нагорного Карабаха Армении. Больше всего их самолюбие задело то, что Кеворков накануне 60-й годовщины событий 1915 года на территории Османской империи, затронув тему т.н. геноцида армян. По этой теме Кеворков сказал буквально следующее: "Несколько лет назад в г. Степанакерте среди некоторой части молодежи нелегально распространялся материал о судебном процессе над Согомоном Тейляряном, кстати, отпечатанный на пишущей машинке областной прокуратуры, под носом у бывших его руководителей. Чем заслужил такой интерес к своей персоне Согомон Тейлярян? Оказывается, тем, что он, будучи дашнакским террористом, застрелил в Берлине одного из главарей движения младотурок Талят-пашу.... Однако давайте попытаемся разобраться в том, насколько правомерны действия лиц, которые по существу стали пропагандистами “героизма" дашнакских террористов...”. Гнев негодования авторов вызвало то, что Кеворков, являясь армянином, вместо того чтобы использовать высокую партийную трибуну для клеймения крепкими эпитетами виновников «геноцида армян», обошелся более мягкими выражениями при оценке личности Талята паши, назвав его «неприятным человеком» ${ }^{88}$.(9) Еще большее негодование авторов писем вызвало передовица в газете «Правда» от 29 мая 1975 года, посвященная мартовскому партийному пленуму в НКАО и данная в ней высокая оценка выступлению Б.Кеворкова. В передовице отмечалось: «Пленум Нагорно-Карабахского обкома Компартии Азербайджана решительно осудила беспринципную позицию бывшего состава бюро по отношению к отдельным политически незрелым людям, допускавшим идеализацию старины, прославления патриархальщины, отход от партийных классовых позиций в оценке исторических событий» ${ }^{89}$.

О последствиях выступления Б.Кеворкова в 1975 году вспоминал позже и Г.Алиев: «...Националисты вновь подняли головы и начали всевозможные провокации против партийного комитета НКАО и, в первую очередь, против Кеворкова. Пошли

\footnotetext{
${ }^{88}$ Там же.

${ }^{89}$ Правда, 1975, 29 мая
} 
телеграммы в Москву, в другие регионы, ситуация накалялась. Через 2 месяца мы встретились в Москве с Демирчяном и поговорили с ним четыре часа. Я довел до его сведения, что все проблемы НКАО, если они есть, должно решать областное руководство и руководство Азербайджана. А вмешательство отдельных лиц в дела Карабаха может принести лишь вред нашим взаимоотношениям, и мы не можем этого позволить...Ситуация была вновь стабилизирована» ${ }^{90}$.

В очередной раз Б.Кеворков попал в опалу своих соплеменников, когда в 1977 году в шестом номере журнала «Проблемы мира и социализма», который издавался в Праге на 32 языках и распространялся в 145 странах мира, была опубликована интервью с ним под названием «Мы видели братство наций». Авторы интервью - член национального совета Компартии Индии Сарада Митра и член ЦК Иракской компартии Адель Хаба побывали в Азербайджанской ССР по приглашению ЦК КПСС, чтобы познакомиться с развитием национальных отношений. В НКАО они встретились с первым секретарем Нагорно-Карабахского обкома партии Кеворковым и задали ему вопрос, почему Нагорный Карабах входит в состав Азербайджанской ССР, а не Армянской, от которой отделяет его лишь узкая полоска земли. Кеворков ответил: «Хотя армянская автономная область и близка к армянской союзной республике, однако они отделены высокими горами. Армянский народ Нагорного Карабаха обрел государственность в составе Азербайджана и выбрал эту долю добровольно. Край расцвел в составе Азербайджана... Только националисты могут говорить: «Пусть я буду плохо жить, но буду связан с Арменией» ${ }^{91}$.

Едва этот номер лег на стол писателя Серо Ханзадяна, как он написал открытое письмо Л. И. Брежневу. Тем более, что подвернулся удобный повод накануне подготовки принятия новой Конституции СССР в очередной раз напомнить московскому руководству о необходимости передачи Нагорного Карабаха Армении. В начале своего письма Ханзадян вновь вернулся к мартовскому пленуму обкома Нагорного Карабаха в 1975 году, расценив выступление на нем Кеворкова как попытку «облить грязью успехи и достижения социалистической Армении». Подробно остановившись над тезисом из интервью Кеворкова о том, что «армянский народ Нагорного Карабаха обрел государственность в составе Азербайджана и выбрал эту долю добровольно», Ханзадян посчитал подобную «долю», как «несправедливость,

\footnotetext{
${ }^{90}$ Ахундова Э. Личность и эпоха. В 4 частях, часть 2 (1969-1982), с.597-598

${ }^{91}$ Письмо С.Ханзадяна Л.Брежневу. Июль 1977 года. http://russia-armenia.info/node/22938; http://press.karabakh.info/Тринадцать_лет_назад...
} 
которая должна быть ликвидирована». В заключение своего письма в традиционной армянской манере Ханзадян просил: «Дорогой Леонид Ильич! Это не впервые, когда нерешенная проблема Карабаха мешает укреплению дружбы между двумя народами. Вся надежда на то, что Вы решите, наконец, вопрос, который вот уже более полувека олицетворяет саму несправедливость. Находящаяся в пределах нашего единого могучего государства исконно армянская область с более чем 80-процентным армянским населением, армянскими школами, государственным армянским языком, должна находиться в составе Советской Социалистической Армении. Справедливое решение этого вопроса будет расценено народами мира как новое торжество ленинской национальной политики» ${ }^{92}$. В результате первому секретарю ЦК Армении К.Демирчяну пришлось держать ответ перед Москвой за дерзость своего литератора, а Азербайджан в очередной раз не поддался армянской провокации.

В 1975 году в Баку, на Дни советской литературы приехала небезызвестная Мариэтта Шагинян, которая еще в конце 40-х годов подверглась обструкции и вынуждена была просить извинения перед руководством Азербайджана во главе с М.Д. Багировым за то, что в изданной в начале 1946 года в ереванском издательстве «Арменгиз» книге «Советское Закавказье» клеветала на азербайджанское население Карабаха, приписывая ему черты отсталости и грубости, искажала факты из истории и культуры Азербайджана. Побывав в Кировабаде и НКАО, проведя встречи с представителями местной армянской интеллигенции, она приехала в Баку, где её у себя дома принял Гейдар Алиев. Во время встречи, поделившись своими наблюдениями с Алиевым, она вынуждена была признать, что армяне живут в Азербайджане превосходно и «катаются как сыр в масле». Во время встречи Шагинян отметила также, что среди армянской интеллигенции по прежнему существуют настроения о передачи НКАО Армении ${ }^{93}$.

В 1977 году в стране шла полным ходом подготовка к принятию третьей Конституции СССР, получившей в исторической литературе название «Брежневской». Начиная со времени принятия последней Конституции СССР в 1936 году, получившей название «Сталинской», партийный лидер страны по традиции возглавлял комиссию по подготовке основного закона. Накануне этого знаменательного события, армяне следуя своим прежним традициям вновь стали посылать в Москву многочисленные обращения с требованием присоединить НКАО к Армении.

\footnotetext{
${ }^{92}$ Там же.

${ }^{93}$ Караулов А. Вокруг Кремля. Книга политических диалогов. В 2-х частях, часть 1, с. 254
} 
5 июля 1977 года за подписью известной армянской писательницы С.Капутикян, бывшего секретаря обкома НКАО Т.Григоряна, профессора Г.Епископосова, персонального пенсионера союзного значения С.Акопяна и других было направлено в Конституционную комиссию письмо, котором в очередной раз поднимался вопрос о необходимости передачи НКАО и Нахчыванской АССР Армении. С первых предложений авторы письма фальсифицировали исторические факты, выдавая желаемое за действительное. Чтобы обосновать идею пересмотра границ между Арменией и Азербайджаном, они пытались убедить советское руководство, что границы между Арменией и Азербайджаном были установлены в период нахождения у власти в обеих республиках националистов в 1918-1920 гг., в результате межнациональных кровопролитных войн и резни, нашествия в Закавказье германотурецких империалистов. Опять в ход были пущены манипуляции с цифрами о геноциде армян в Турции и Азербайджане. То есть подобной односторонней информацией авторы пытались показать, что жертвами межнациональных столкновений были исключительно армяне, у которых азербайджанцы якобы захватили их земли. Полностью извращая исторические факты, авторы письма пытались доказать, что якобы исконно армянские территории Нахчыван и Нагорный Карабах, Дашкесанский, Шамхорский, Кедабекский, Ханларский и Шаумяновский районы были оккупированы турецкими войсками и переданы Азербайджану. Авторы письма не могли не знать, что именно нерешенность пограничных вопросов и стали причиной кровопролитных войн между двумя государствами, конец которым был положен лишь после установления советской власти в Азербайджане и Армении в 1920 году. Советская власть установила мораторий в этих конфликтах путем создания автономных образований в Нахчыване и Нагорном Карабахе. Авторы письма приводят текст декларации Баксовета от 1 декабря 1920 года, которое фактически было программой большевиков по решению вопроса о спорных территориях между Арменией и Азербайджаном. В декларации предлагалось передать Зангезур и Нахчыван Армении, а Нагорному Карабаху предоставить право на самоопределения. Однако при реализации этой программы в отношении Нахчывана основной помехой для Армении, как считают авторы письма, стала Турция. Однако вопрос о Нахчыване был решен на основе советско-турецкого договора о дружбе и братстве. Что же касается судьбы Нагорного Карабаха, то, по мнению авторов письма, в этом вопросе армянам не дали возможности использовать свое право на самоопределение. Однако почему-то в письме не указывается, кто помешал армянам использовать это право. 
Видимо тогда пришлось бы признать, что вопрос об автономии армян Нагорного Карабаха в составе Азербайджана был решен в партийном порядке эмиссарами Москвы на Кавказе Г.Орджоникидзе и С.Кировым, а не турецко-германскими империалистами и мусаватскими националистами. Таким образом, именно Москва сыграла решающую роль в окончательным определении границ не только между Арменией и Азербайджаном, но и этих республик с Турцией.

Основным аргументом авторов письма в пользу необходимости передачи Нагорного Карабаха Армении являются якобы препятствия, которые чинило азербайджанское руководство для экономического и культурного развития армянского населения области, нехватка земельных фондов в Армении для развития экономики и размещения желающих вернуться на родину зарубежных армян. Авторы письма манипулировали итогами переписей 1926 и 1970 годов, без анализа объективных причин происходивших в НКАО демографических процессов, а именно уменьшения численности армян и увеличения численности азербайджанцев. Они сетовали на то, что подобная ситуация наблюдается и в других регионах Азербайджана, где проживают армяне, особенно в Баку и Кировабаде. Якобы армян лишают право получать образование на родном языке, иметь свой театр и т.д. Вновь была затронута тонкая струна об исторической дружбе армянского и русского народов, о вкладе армян в победу России в русско-персидских и русско-турецких войнах, в установление советской власти и победе над фашизмом в годы Великой Отечественной войны. Поэтому авторы письма делали вывод, что армянский народ имеет исключительное право, чтобы учитывались его интересы и чаяния, законные стремления сохранить свои исторические, материальные и духовные ценности, на воссоединение с Арменией тех районов, которые якобы были отторгнуты от неё турецкими нашествиями и азербайджанскими мусаватистами. При этом просто цинично звучали предложения в адрес Азербайджана пожертвовать частью своих исторических территорий в пользу Армении в знак братских интересов, от чего якобы Азербайджан нисколько не пострадал бы. При этом сопоставлялись размеры территорий и численность населения двух республик, чтобы показать превосходство Азербайджана и призвать руководство страны удовлетворить территориальные притязания Армении, которой хронически не хватает пригодных земель для экономического развития, размещения армянских эмигрантов. В конце письма её авторы вновь попытались доказать, что пересмотр границ между Арменией и Азербайджаном будет соответствовать принципам демократии, коммунистическому строительству и подлинной дружбе народов. Поэтому 
предлагалось внести соответствующие изменения в Конституцию СССР и рассмотреть вопрос о целесообразности включения Нахчыванской ССР и НКАО в состав Армении. В короткой справке, приложенной к письму 22 июля 1977 года, заведующий сектором Отдела организационно-партийной работы ЦК КПСС А.Санников сообщал, что с одним из авторов письма С.Акопяном по существу вопроса беседовал инструктор Отдела организационно-партийной работы ЦК КПСС Громыко, а 11 августа 1977 года о письме было доложено секретарю ЦК КПСС И.Капитонову ${ }^{94}$.

10 ноября 1999 года, принимая в президентском дворце группу азербайджанских писателей, Гейдар Алиев так вспоминал о событиях двадцатилетней давности: «В 1977 году принималась новая Конституция СССР. Была назначена Конституционная комиссия, её председателем был Брежнев, мы были членами комиссии. Я был представителем Азербайджана. Периодически комиссия проводила обсуждения. Их в то время проводил секретарь Центрального Комитета академик Пономарев (Б.Пономарев-секретарь ЦК). Брежнев не настолько участвовал в этом. Однажды я приехал в Москву на заседание комиссии. Увидел, что поступило значительное количество заявлений о том, что «необходимо вывести Нагорный Карабах из состава Азербайджана и передать Армении». Вижу, что Пономарев говорит, что этот вопрос надо вынести на обсуждение комиссии-армяне и на него воздействовали. Вы понимаете, что означает сам факт вынести этот вопрос на обсуждение комиссии? Ещё за день до заседания комиссии я сильно возражал против этого, но увидел что нет... Я вновь пошел к ныне покойному Брежневу. Сказал ему: что это такое? Этого не должно быть! Он позвонил Пономареву и сказал: сними его» ${ }^{95}$.

И даже после данного решения поток заявлений и писем в Москву, которые сопровождались различными справочными материалами и иными документами от представителей так называемой армянской общественности не прекращался. Под давлением этих обращений 23 ноября 1977 года в Протокол заседания Президиума Совета Министров СССР была внесена даже следующая формулировка: «Вследствие ряда исторических обстоятельств несколько десятилетий назад Нагорный Карабах искусственно был присоединен к Азербайджану. При этом не были учтены историческое прошлое области, еe национальный состав, желание народа и экономические интересы. Прошли десятилетия и вопрос о Карабахе продолжает склоняться, вызывать беспокойство и моменты недоброжелательности между двумя

\footnotetext{
${ }^{94}$ Российский Государственный Архив Новейшей Истории, фонд 100, опись 5, дело 696, листы 173-183.

95 Алиев Г. Наша независимость вечна. Многотомник. Том 23. Баку, 2008, с.96.
} 
соседними народами, связанными вековой дружбой. Надо присоединить Нагорный Карабах к Армянской ССР. Тогда все станет на свои законные места» ${ }^{96}$. Но вскоре, видимо, взвесив все за и против, высшее советское руководство сняла вопрос с повестки дня. Однако эти события не прошли бесследно для Г.Алиева. Как вспоминал позже академик Играр Алиев, в начале 1978 года Г.Алиев вызвал его к себе и сказал: «Армяне подняли перед руководством страны вопрос о передаче Нагорного Карабаха Армении. Надо подготовить основательную справку по этому вопросу». Академик напомнил партийному лидеру, что сразу после войны подобная справка была подготовлена для Мир Джафара Багирова, в её составлении участвовал он сам. Играр Алиев попросил отыскать данный документ в недрах партийного архива. «На следующий день Гейдар Алиев вновь принял меня. Он протянул мне справку, написанную нами 30 лет назад. В течение месяца я подготовил обширную справку об истории Нагорного Карабаха и представил её в ЦК. Назавтра основные положения справки были обсуждены и одобрены на заседании Бюро Центрального Комитета. Позднее я узнал, что Гейдару Алиеву удалось во время пресечь очередную провокацию армян против азербайджанского народа» ${ }^{97}$.

Помнится, во время обсуждения вопроса о событиях в Сумгаите на заседании Политбюро ЦК КПСС 29 февраля 1988 года Генеральный секретарь ЦК КПСС М.Горбачев удивленно сказал: «Оказывается, секретарь Степанакертского обкома за 14 лет ни разу не был в Армении, хотя Нагорный Карабах - это ведь армянская автономия» ${ }^{98}$. Однако Горбачев не мог не знать, что в Ереване вовсе не были рады Кеворкову. Причиной тому были имевшие место жесткие выступления Кеворкова в адрес отдельных представителей армянской «интеллигенции», которые своими националистическими высказываниями пытались обострить ситуацию в автономии. С другой стороны, НКАО постоянно посещали ученые, писатели, журналисты, деятели культуры и искусства Армении, которым оказывался здесь достойный прием, и которые уезжали из Нагорного Карабаха, убежденные в несомненной значительности тех преобразований, которые произошли во всех сферах жизни НКАО.

Очередной такой вояж произошел 5-6 сентября 1980 года. Как следует из отчета Б.Кеворков в ЦК КП Азербайджана от 26 сентября 1980 г., в порядке экскурсии

\footnotetext{
${ }^{96}$ Борьба армян за воссоединение НКАО с Советской Арменией. Сборник документов и материалов, c. 25

${ }^{97}$ Гейдар Алиев и вопросы истории Азербайджана // Газета «Элм», 2002, 10 may, № 13-16, s.15-16

98 Заседание Политбюро ЦК КПСС от 29 февраля 1988 г. / Журнал "Родина", № 4, 1994 г., с. 82-90
} 
в автономии побывала группа сотрудников редакции газеты «Советакан Айастан» (орган ЦК КП Армении, Верховного Совета и Совета Министров Армянской ССР), возглавляемая зам.редактором этой газеты Н.Саруханяном. Члены группы по их же просьбе были приняты секретарем обкома НКАО Б.Кеворковым. Кеворков ознакомил гостей со значительными успехами, достигнутыми в развитии экономики и культуры области, сообщил гостям о тех разительных переменах, которые произошли в НКАО после августовского пленума ЦК КП Азербайджана 1969 года. В отчете, подготовленном на имя первого секретаря ЦК КП Азербайджана Гейдара Алиева, Кеворков особо отмечал, что приехавшие журналисты «плохо представляли себе сегодняшний Нагорный Карабах, не только не знали о его достижениях в экономическом и социальном развитии, но и, будучи дезинформированы инсинуациями, распространяемыми лицами подобными Зорию Балаяну, Баграту Улубабяну, Леониду Гурунцу, поначалу были настроены по отношению к руководству и активу партийной организации области, по крайней мере, недружелюбно». Согласно отчету Кеворкова, во время первой встречи гости выражали сомнение относительно достоверности тех статистических сведений, которые характеризуют уровень нынешнего социально-экономического развития НКАО, выражали озабоченность о якобы прогрессирующем уменьшении населения НКАО. Однако, как видно из отчета, экскурсия гостей по Степанакерту и Шуше, Мардакертскому и Мартунинскому районам, знакомство с хозяйствами этих районов, произвело на них большое впечатление. Все журналисты с одобрением говорили об увиденном, подчеркивали, что их приезд в НКАО и ознакомление с ней, сняли старое, навеянное дезинформацией, неправильное представление о Нагорном Карабахе. В отчете Кеворков особо подчеркнул, что подобные встречи подтвердили правильность неоднократных указаний Г.Алиева о том, что не следует уклоняться от встреч с представителями интеллигенции Армении, когда они просят этого, а надо принимать их и использовать встречи для информации о достижениях в развитии экономики и культуры НКАО. ${ }^{99}$

В целом в период руководства республикой Гейдар Алиев как истинный государственник стремился развивать все регионы республики и не разделял своих граждан по этнической принадлежности. Ведь все жили в едином государстве и искренне думали об общем благе страны. И в начале нагорно-карабахского

\footnotetext{
99 Архив Политических Документов Управления Делами Президента Азербайджанской Республики , фонд 1, опись 67, дело 198, листы 193-198
} 
конфликта, и после Гейдар Алиев был убежден, что этот вопрос был задуман не в самой НКАО. В беседе с корреспондентом газеты «Вашингтон пост» в Москве Девидом Ремником Г.Алиев рассказывал: «За 14 лет работы на посту первого секретаря ЦК КП Азербайджана, я каждый год, иногда не один раз, бывал в Нагорном Карабахе, и ни один человек из этой автономной области не ставил передо мной вопрос о том, что НКАО нужно вывести из состава Азербайджана и передать Армении. Никто, понимаете ли! Отдельные националистические настроения были в Армении, там кое-кто вынашивал такие планы, но они не были поддержаны населением НКАО» ${ }^{100}$. В то же время позже возвращаясь к своей поездки в Нагорный Карабах по случаю 50-й годовщины НКАО, Алиев вспомнил одну фразу из своего выступления, которую, как он считал, армянские националисты ему не простили : «Я сказал тогда: НКАОнеотделимая часть Азербайджана и такой она останется навсегда ${ }^{101}$. После того как я уехал из Азербайджана, к сожалению, после событий 1988 года они потихоньку зашевелились. Контроль над Нагорным Карабахом был ослаблен, и они сделали это» ${ }^{102}$.

Автор книги «Черный сад» Томас де Ваал убежден, что именно отстранение Гейдара Алиева от высшего руководства Советского Союза в октябре 1987 года полностью развязала руки армянам. По мнению автора, армянские националисты имели непосредственное отношение к отставке Гейдара Алиева: «Они задумали кампанию, -как он писал- по дискредитации азербайджанского патриарха Гейдара Алиева, который, как им представлялось, мог стать главным противником идеи отделения Карабаха и заблокировать весь процесс. В одном из своих интервью Гейдар Алиев вспоминал, что в 1987 году получил письмо от одного из активистов карабахского движения Игоря Мурадяна, полный угроз и оскорблений в свой адрес. Автор письма обвинял Г.Алиева в том, что он мешает присоединению Нагорного Карабаха к Армении. Письмо сопровождалось большим списком, состоявшим из фамилий азербайджанцев и турков, ставших жертвами армянского террора ${ }^{103}$. Видимо, тем самым автор письма угрожал Г.Алиеву, что если он не сойдет с пути армян, его ожидает подобная участь. Интересно, что тот же Мурадян в марте 1987 года направил письмо на имя кандидата члена в Политбюро, идеолога Перестройки А.Яковлева, в котором открытым текстом обвинял Гейдара Алиева в том, что именно он виновен «

\footnotetext{
${ }^{100}$ Караулов А. Вокруг Кремля. Книга политических диалогов. В 2-х частях, часть 1,с.271

${ }^{101}$ Интервью Гейдара Алиева / Журнал “Ulduz", 1990, № 6, с.69

102 Алиев Г. Наша независимость вечна. Многотомник. Том 23. Баку, 2008,с.94

${ }^{103}$ Интервью Гейдара Алиева / Журнал “Ulduz”, 1990, № 6,c.71
} 
укоренении раздела Восточной Армении (Армянской ССР, НКАО, Нахичеванской ACСР)». В письме его автор указывал, что в Верховный суд СССР направлено обращение с заявлением об иске против Гейдара Алиева и по этому делу собран и представлен материал на 600 страниц ${ }^{104}$. Данное обращение И.Мурадяна лишний раз доказывает, что после начала Перестройки армянские националисты настолько были раскрепощены в своих действиях, что могли вступать с обвинениями против действующего члена Политбюро и одного из руководителей Советского правительства. Безусловно, они не осмелились бы на подобный шаг, не имея поддержку от Генерального секретаря ЦК КПСС М.Горбачева и его армянского окружения в лице А.Аганбекяна, Г.Шахназарова и других. Не случайно Г.Шахназаров в своих воспоминаниях писал, что Г. Алиев обвинял его и других армян, близких к Горбачеву, в отторжении Карабаха от Азербайджана ${ }^{105}$. Как пишет Т.де Ваал, карабахским активистам удалось даже заручиться молчаливой поддержкой руководителя компартии Армении Карена Демирчяна, который, говорят, был очень рад закату политической карьеры своего оппонента в высшем партийном руководстве СССР. Вспоминая об этом бывший первый секретарь ЦК КП Армении К.С.Демирчян в 1990 году отмечал: «Нам удалось сделать самое главное - сместить Алиева до начала (карабахского) движения. Это было очень важно» ${ }^{106}$.

Таким образом, накануне начала последней фазы армяно-азербайджанского Нагорно-Карабахского конфликта в 1988 года армянские притязания на Нагорный Карабах уже носили систематический характер. Хотя они носили латентный характер, однако постоянно держали в напряжение азербайджанское руководство. Руководству Азербайджана во главе с Гейдаром Алиевым удавалось нейтрализовать их благодаря оперативному вмешательству в процессы, которые происходили вокруг автономной области. Безусловно, личный авторитет Гейдара Алиева в высшем руководстве страны являлся главным препятствием на пути реализации армянами своих экспансионистских планов.

\section{Streszczenie:}

Artykuł analizuje roszczenia terytorialne Armenii do Autonomicznego Regionu Górskiego Karabachu Azerbejdżanu w przededniu rozpoczęcia ostatniej fazy konfliktu ormiańsko-azerbejdżańskiego w Górskim Karabachu w 1988 roku. Podczas przywództwa

\footnotetext{
${ }^{104}$ Российский Государственный Архив Новейшей Истории, фонд 100,опись 5, дело 631, листы 1-2

${ }^{105}$ Шахназаров Г. С вождями и без них. Москва, 2001, с.45

${ }^{106}$ Томас де Ваал Черный сад. Армения и Азербайджан между миром и войной. М., 2005, с.34-35
} 
republiki Gejdara Alijewa (1969-1982), chociaż te twierdzenia były ukryte, nieustannie utrzymywały w napięciu przywództwo Azerbejdżanu. Przywództwo Azerbejdżanu, na czele z Gejdarem Alijewem, zdołało je zneutralizować dzięki szybkiej interwencji w procesy zachodzące w regionie autonomicznym. Niewątpliwie osobisty autorytet Gejdara Alijewa w ścisłym kierownictwie kraju był główną przeszkodą na drodze Ormian w realizacji ich planów ekspansjonistycznych.W artykule wykorzystano dokumenty z archiwów Federacji Rosyjskiej i Republiki Azerbejdżanu, wspomnienia Hejdara Alijew i inne znane postacie polityczne okresu sowieckiego.

\section{Słowa kluczowe:}

Górski Karabach, Azerbejdżan, Armenia, terytorium, Gejdar Alijew

\section{Key words:}

Nagorno-Karabakh, Azerbaijan, Armenia, territory, Heydar Aliyev

\section{Bibliografia:}

1. Алиев Г. Наша независимость вечна. Многотомник. Том 23. Баку, 2008.

2. Алиев Г. Наша независимость вечна. Многотомник. Том 32. Баку, 2010.

3. Архив Политических Документов Управления Делами Президента Азербайджанской Республики, фонд 1, опись 67, дело 198.

4. Ахундова Э. Личность и эпоха. В 4 частях, часть 2 (1969-1982).Баку, 2007.

5. Борьба армян за воссоединение НКАО с Советской Арменией. Сборник документов и материалов. Ереван. 2011.

6. Брутенц К. Тридцать лет на Старой площади. Москва,1998.

7. Газарян В.Только разобравшись с прошлым, можно строить будущее. http://demonewspaper.com/russian/2008-2/n8-may-2008/

8. Гейдар Алиев и вопросы истории Азербайджана // Газета «Элм», 2002, 10 may, № $13-16$

9. Гусейнбейли А. Интервью с генералом разведки. Баку, 1997.

10. Заседание Политбюро ЦК КПСС от 29 февраля 1988 г. / Журнал "Родина",1994, № 4 .

11. Интервью Гейдара Алиева / Журнал “Ulduz”, 1990, № 6.

12. Караулов А. Вокруг Кремля. Книга политических диалогов. В 2-х частях, часть 1. М., 1990.

13. Мирзоян Г. «Эскизы к биографии. От Геворга Алиханяна до Сурена Арутюняна» Газетная версия книги. https:/forum.hayastan.com/topic/39542-гмирзоян-«советские-правители-армении»/

14. Письмо С.Ханзадяна Л.Брежневу. Июль 1977 года. http://russiaarmenia.info/node/22938; http://press.karabakh.info/Тринадцать_лет_назад...

15. Правда, 1975, 29 мая

16. Российский Государственный Архив Новейшей Истории, фонд 100,опись 5, дело 631.

17. Российский Государственный Архив Новейшей Истории, фонд 100, опись 5, дело 696. 
18. Томас де Ваал Черный сад. Армения и Азербайджан между миром и войной. М., 2005.

19. Шахназаров Г. С вождями и без них. Москва, 2001.

20. http://www.aniarc.am/2015/04/30/karabakh-diary-russian-kevorkov/ 